\section{Vital capacity rapid inhalation induction technique: comparison of sevoflurane and halothane}

Induction of anaesthesia using the vital capacity rapid inhalation induction (VCRII) technique with either sevoflurane or halothane was compared. The induction time, characteristics, and acceptability were assessed. Thirty-two volunteers were given one of the vapours: 17 received sevoflurane and 15 halothane. Subjects were unpremedicated and breathed approximately $2.6 \times$ minimum alveolar concentration (MAC) equivalent of either agent. There were no differences in the patients cardiovascular or respiratory variables. The mean time for induction of anaesthesia with halothane (153 $\pm 46 \mathrm{sec}, S D)$ was slower than with sevoflurane $(81 \pm 22 \mathrm{sec}, S D, P<0.05)$, reflecting its higher blood:gas solubility. There were fewer induction complications such as coughing and movement in the sevoflurane than in the halothane group. Subjects in the sevoflurane group found the smell of anaesthetic more acceptable than those in the halothane group (65\% vs $13 \%$, respectively). Subjects in both groups had no objection to undergoing the procedure again. It is concluded that both halothane and sevoflurane are effective in VCRII of anaesthesia without premedication. However, the slower speed of induction with halothane frustrated the anaesthetist because of the longer induction time, and may increase the chance of pronounced excitatory phenomena occurring.

Cette étude compare linduction à l'halothane à celle du sévoflurane avec la technique dinduction rapide par inhalation jusqu'à la capacité vitale. Trente-deux volontaires ont fait l'objet

\section{Key words:}

ANAESTHESIA: induction;

ANAESTHETICS VOLATILE: halothane, sevoflurane.

From the Asahikawa Medical College, Department of Anaesthesia, 45-3-11, Nishikagura, Asahikawa-city, Hokkaido 078, Japan.

Address correspondence to: M. Yurino, Asahikawa Medical College, Department of Anaesthesia, 4-5-3-11 Nishikagura,

Asahikawa-city, Hokkaido 078, Japan.

Accepted for publication 30th April, 1991. de cette épreuve et chacun d'eux a reçu un des deux agents: 17 ont reçu le sévoflurane et 15, l'halothane. Non prémédiqués, ils ont inspiré approximativement 2,6 fois léquivalent de la concentration alvéolaire minimum (CAM) de l'un ou de l'autre des agents. Il n'y avait de différences entre les paramètres cardiovasculaires et respiratoires. La durée moyenne de lïnduction de l'anesthésie avec l'halothane (153 $\pm 46 \mathrm{sec}, S D)$ a été plus lente que celle produite par le sévoflurane $(81 \pm 22 \mathrm{sec}, S D$, $P<0,05)$, ce qui reflète son coefficient de solubilité sang:gaz plus élevé. Lincidence des complications telles que la toux et les mouvements a été moindre avec sévoflurane qu'avec lhalothane. Les sujets du groupe sévoflurane ont trouvé son odeur plus acceptable que ceux de lhalothane $63 \%$ et $13 \%$ respectivement). Les sujets des deux groupes nauraient pas eu d'objection à répéter l'épreuve. En conchusion, lhalothane et le sévoflurane se prêtent tous deux à cette technique dinduction rapide. La lenteur de l'induction à l'halothane a été frustrante pour l'anesthésiste et pourrait augmenter lincidence des phénomènes d'excitation.

Two previous studies, in over 200 healthy volunteers, demonstrated the safety and acceptability of using the vital capacity rapid inhalation induction (VCRII) technique to induce anaesthesia with halothane and oxygen. ${ }^{1,2}$ In 1986, Wilton and Thomas ${ }^{3}$ modified the technique by using halothane in nitrous oxide and oxygen and confirmed, in 100 patients, the acceptability of the technique for rapid inhalation induction of anaesthesia.

The VCRII technique has certain advantages over conventional inhalational or intravenous induction of anaesthesia, which include prompt induction without a prolonged excitatory phase, and full recovery without "hangover."

We assessed the use of the newly developed agent, sevoflurane, as an alternative to halothane for VCRII.

\section{Methods}

The study was approved by the Hospital Human Research Committee, and informed consent was obtained 
from each volunteer. Thirty-two healthy adult volunteers, who had no previous experience of anaesthesia induction, were randomly designated to receive either $4.5 \%$ sevoflurane $(\mathrm{S})$ or $2.0 \%$ halothane $(\mathrm{H})$. These concentrations represent approximately $2.6 \times$ minimum alveolar concentration (MAC) equivalent of each agent. Seventeen subjects were assigned to the $S$ Group and 15 to the H Group.

The selected inhalational agent, in oxygen, was delivered from an Ohmeda anaesthetic machine fitted with Ohmeda calibrated vaporisers and a circle system with an approximate volume of eight litres. In each experiment, the circle system was flushed with oxygen for more than four minutes at $8 \mathrm{~L} \cdot \mathrm{min}^{-1}$ with the vaporiser set at the desired concentration. Excess gas was vented through the popoff valve and breathing hoses.

Volunteers received no premedication and breathed air before induction of anaesthesia. They were instructed to breathe out to residual volume, their faces were covered by the mask connected to the primed circle system, and then they were asked to take a vital capacity breath (VCB) and to hold their breath for as long as they were comfortable. Following the VCB, the volunteers, through spontaneous respiration, were given the same anaesthetic mixture for up to five minutes. Then, they breathed oxygen until they regained consciousness.

Loss of consciousness (LOC) was defined as failure to respond to the command "open your eyes." Commands were repeated at ten-second intervals until the subjects failed to respond. Induction time and the presence of excitatory phenomena were recorded by an independent observer. Induction time was defined as the interval from the time at which the subject's lung volume reached total lung capacity (the end of the vital capacity inspiration) until LOC

Anaesthetic induction was defined as "complicated" if one or more of the five categories established by Lamberty occurred. ${ }^{5}$ A single cough, laryngospasm, breath holding, movement of a limb, or excessive salivation (enough secretions to wet our hands) were recorded.

As it is difficult to assess such observations objectively, the observer who was "blind" to the agent used, asked the subjects, immediately after emergence from anaesthesia, to recall how many commands they heard during induction of anaesthesia, to characterise the smell of the anaesthetic agent into three categories (pleasant: subjects liked, or did not mind smell, unpleasant: very pungent or not tolerable, no comment: others), and whether they would have any objection to undergoing VCRII again.

Monitoring included an automatic noninvasive blood pressure recorder with an ECG oscilloscope, pulse oximeter (Colin, Japan) and multi-gas monitor (Datex, USA). The gas monitor was calibrated every day before

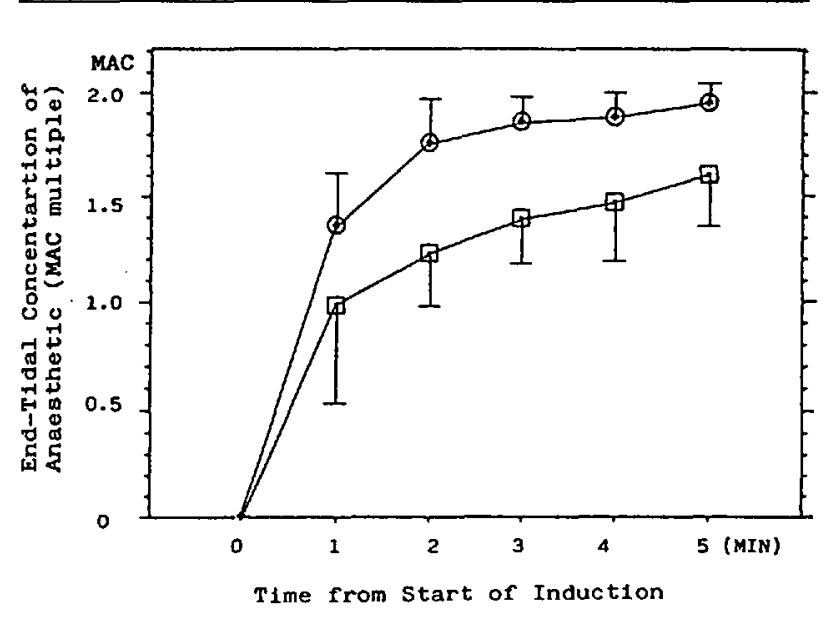

FIGURE End-tidal concentration (ex/rend as MAC multiple) of sevoflurane $(O)$ increased more rapidly with VCRII than halothane (D).

the experiment and three or four subjects were sequentially studied in a day. Respiratory gases were sampled from the elbow connector with the mask, at a flow rate of $150 \mathrm{ml} \cdot \mathrm{min}^{-1}$, to monitor end-tidal and inspired concentrations of anaesthetic gases continuously. From these data, the sevoflurane and halothane concentrations were recorded.

All results were expressed as mean \pm SD. Statistical analyses were carried out using chi-square and Fisher's exact tests on the variables of complications, unpaired $t$ test on variables of subjects and induction time, and ANOVA for the variables of blood pressure, heart rate, and anaesthetic concentrations. A $P$ value $<0.05$ was considered to be statistically significant.

\section{Results}

The groups were demographically similar with no differences between them in terms of age, sex, weight, or height (Table I). Anaesthesia was introduced successfully in all subjects in both groups. The mean induction time was slower with halothane than with sevoflurane (153 $\pm 46 \mathrm{sec}$ vs $81 \pm 22 \mathrm{sec}, P<0.05$ ). End-tidal halothane concentrations increased more slowly than those of sevoflurane (Figure, $P<0.05$ ).

The cardiovascular changes were similar in both groups, (Table II). Systolic and diastolic blood pressures (BP) gradually decreased $(P<0.05)$. Heart rates did not change. There were no differences between halothane and sevoflurane with respect to arterial oxygen saturation $(99 \% \pm 0.6 \%, 99 \% \pm 0.2 \%$, respectively) during the induction of anaesthesia.

Overall, subjects in the S Group had fewer complications than did those in the H Group (Table III). Coughing and movements were mild in both groups. Serious 
TABLE I Demographic data

\begin{tabular}{|c|c|c|c|c|c|}
\hline & & & Age $(y r)$ & Weight (kg) & Height $(\mathrm{cm})$ \\
\hline & Men & Women & $\begin{array}{l}\text { Mean } S D \\
\text { (range) }\end{array}$ & $\begin{array}{l}\text { Mean SD } \\
\text { (range) }\end{array}$ & $\begin{array}{l}\text { Mean SD } \\
\text { (range) }\end{array}$ \\
\hline Sevoflurane $(n=17)$ & 12 & 5 & $\begin{array}{l}25.6 \pm 2.4 \\
(23-32)\end{array}$ & $\begin{array}{l}59.8 \pm 7.1 \\
(47-75)\end{array}$ & $\begin{array}{l}167.4 \pm 7.0 \\
155-178)\end{array}$ \\
\hline Halothane $(n=15)$ & 10 & 5 & $\begin{array}{l}24.7 \pm 2.7 \\
(23-33)\end{array}$ & $\begin{array}{l}61.4 \pm 9.1 \\
(45-75)\end{array}$ & $\begin{array}{l}168.7 \pm 7.6 \\
(155-180)\end{array}$ \\
\hline
\end{tabular}

TABLE II Comparison of cardiovascular variables. Mean (SD)

\begin{tabular}{|c|c|c|c|c|c|c|}
\hline & \multirow{2}{*}{$\begin{array}{l}\begin{array}{l}\text { Before } \\
\text { induction }\end{array} \\
\text { Control }\end{array}$} & \multicolumn{5}{|c|}{ Afier induction, Time (min) } \\
\hline & & 1 & 2 & 3 & 4 & 5 \\
\hline \multicolumn{7}{|l|}{ Sevoflurane $(n=17)$} \\
\hline Systolic BP (mmHg) & $\begin{array}{l}119 \\
(11)\end{array}$ & $\begin{array}{l}118 \\
(14)\end{array}$ & $\begin{array}{l}108^{*} \\
(13)\end{array}$ & $\begin{array}{l}103^{*} \\
(11)\end{array}$ & $\begin{array}{c}99 * \\
(9)\end{array}$ & $\begin{array}{r}98^{*} \\
(10)\end{array}$ \\
\hline Diastolic BP (mmHg) & $\begin{array}{c}66 \\
(7)\end{array}$ & $\begin{array}{c}65 \\
(8)\end{array}$ & $\begin{array}{l}58^{*} \\
(7)\end{array}$ & $\begin{array}{l}53^{*} \\
(7)\end{array}$ & $\begin{array}{l}50^{*} \\
(8)\end{array}$ & $\begin{array}{l}51^{*} \\
\text { (7) }\end{array}$ \\
\hline Heart rate (beats $\cdot \mathrm{min}^{-1}$ ) & $\begin{array}{c}72 \\
(14)\end{array}$ & $\begin{array}{c}72 \\
(12)\end{array}$ & $\begin{array}{c}73 \\
(13)\end{array}$ & $\begin{array}{c}74 \\
\text { (13) }\end{array}$ & $\begin{array}{c}75 \\
(14)\end{array}$ & $\begin{array}{c}73 \\
(13)\end{array}$ \\
\hline Halothane $(n=15)$ & & & & & & \\
\hline Systolic BP (mmHg) & $\begin{array}{l}118 \\
\text { (11) }\end{array}$ & $\begin{array}{r}114^{*} \\
(8)\end{array}$ & $\begin{array}{l}113^{*} \\
(10)\end{array}$ & $\begin{array}{r}107^{*} \\
(7)\end{array}$ & $\begin{array}{l}108^{*} \\
(10)\end{array}$ & $\begin{array}{l}104^{*} \\
(10)\end{array}$ \\
\hline Diastolic BP (mmHg) & $\begin{array}{l}67 \\
(8)\end{array}$ & $\begin{array}{l}62^{*} \\
\text { (7) }\end{array}$ & $\begin{array}{l}62^{*} \\
(9)\end{array}$ & $\begin{array}{l}58^{*} \\
(8)\end{array}$ & $\begin{array}{l}57^{*} \\
(9)\end{array}$ & $\begin{array}{l}54^{*} \\
(9)\end{array}$ \\
\hline Heart rate (beats ' $\mathrm{min}^{-1}$ ) & $\begin{array}{c}70 \\
\text { (11) }\end{array}$ & $\begin{array}{l}74 \\
\text { (9) }\end{array}$ & $\begin{array}{c}75 \\
(12)\end{array}$ & $\begin{array}{l}75^{*} \\
\text { (7) }\end{array}$ & $\begin{array}{c}74^{*} \\
\text { (I1) }\end{array}$ & $\begin{array}{l}72 \\
(9)\end{array}$ \\
\hline
\end{tabular}

Control vs each value.

$* P<0.05$.

TABLE III Incidence of complications during induction of anaesthesia

\begin{tabular}{lll}
\hline & $\begin{array}{l}\text { Sevoflurane } \\
(n=17)\end{array}$ & $\begin{array}{l}\text { Halothane } \\
(n=15)\end{array}$ \\
\hline $\begin{array}{l}\text { Induction } \\
\text { - Complicated }\end{array}$ & $3 / 17(17.6 \%)^{*}$ & $5 / 15(33.3 \%)$ \\
- Uncomplicated & $14 / 17(82.4 \%)$ & $10 / 15(66.7 \%)$ \\
1 Coughing & - & $3 / 15(20.0 \%)$ \\
2 Laryngospasm & - & - \\
3 Breath holding & - & - \\
4 Movement & $3 / 17(17.6 \%)$ & $2 / 15(13.3 \%)$ \\
5 Secretion & - & - \\
\hline
\end{tabular}

$* P<0.05$ vs halothane.

complications, severe coughing, laryngospasm, breath holding, and excessive salivation did not occur in any subject.

A survey of subjects after emergence from anaesthesia revealed that the experience was viewed positively and, without exception, no subjects would have any objection
TABLE IV Acceptability and smell

\begin{tabular}{lll}
\hline & Sevoflurane & Halothane \\
\hline Same induction again? & & \\
- Yes & $17 / 17(100 \%)$ & $15 / 15(100 \%)$ \\
- No comment & - & - \\
- No & - & - \\
& & \\
Smell & $11 / 17(64.7 \%)^{*}$ & $2 / 15(13.3 \%)$ \\
- Pleasant & $5 / 17(29.4 \%)$ & $6 / 15(40.0 \%)$ \\
- No comment & $1 / 17(5.9 \%)$ & $7 / 15(46.7 \%)$ \\
- Unpleasant & & \\
\hline$* P<0.05$. & &
\end{tabular}

to undergoing the procedure again. Nonetheless, sevoflurane was classified as pleasant smelling more frequently than was halothane ( $P<0.05$, Table IV). Subjects given halothane remembered $3.4 \pm 1.5$ total commands before LOC compared with $2.1 \pm 1.3$ commands by those given sevoflurane. 


\section{Discussion}

In 1954, Bourne ${ }^{6}$ reported a new technique for using cyclopropane for outpatient dental surgery that included holding a VCB of cyclopropane until LOC. Cyclopropane offered an alternative to intravenous induction; LOC was rapid, arterial BP was well maintained, and emergence occurred without delay. Unfortunately, the flammable nature of cyclopropane forced its discontinuation.

In 1985, Ruffle $e t$ al. reported on the use of Bourne's technique with halothane 4\% in oxygen (approximately 5.2 MAC). Loss of consciousness was achieved in less than $3.5 \mathrm{~min}$ in 15 of 16 patients. More recently, Wilton and Thomas ${ }^{3}$ demonstrated that the addition of nitrous oxide to the inspired gas mixture (halothane $4 \%$ in nitrous oxide $67 \%$ and oxygen $33 \%$ ) further reduces induction time to a mean of $83 \mathrm{sec}$.

The VCRII technique has advantages over intravenous induction of anaesthesia because anaesthesia may be induced without intravenous access. The transition from the induction to the maintenance phase is usually smooth and the hangover associated with intravenous anaesthetic agents, particularly barbiturates, can be avoided. ${ }^{4}$ Therefore, we tested sevoflurane in VCRII as an alternative to halothane.

Halothane induction with VCRII required twice as long as did sevoflurane. We found that end-tidal concentrations of halothane increased more slowly than those of sevoflurane. With inhalational anaesthesia, the steadystate concentration of the agent in the brain correlates well with the alveolar concentration. ${ }^{7}$ During induction, rapid uptake of a volatile agent in body tissues decreases the alveolar concentration. Thus, the slow induction of anaesthesia with halothane is caused by its high blood:gas solubility coefficient.

To achieve a rapid inhalational induction using VCRII, high concentrations of volatile agents should be used. We used sevoflurane $4.5 \%$ in this study and would have preferred a higher concentration to reduce the time to loss of consciousness. However, the concentration that can be delivered by the Ohmeda Vapour vaporiser is limited to $4.5 \%$ when the fresh gas flow is $8 \mathrm{~L} \cdot \mathrm{min}^{-1}$. The new Penlon vapour vaporiser can deliver a $7.5 \%$ concentration with the same fresh gas flow. We are continuing to test VCRII with $7.5 \%$ sevoflurane in oxygen. Another technique to achieve rapid inhalational induction is by taking multiple vital capacity breaths. Ruffle compared singlebreath and triple-breath inductions with halothane in oxygen. ${ }^{2}$ The triple-breath induction took only $60 \%$ as much time as single-breath induction. However, in this study we did not employ triple-breath induction because of its variability. Triple-breath induction is not suitable for comparison of induction times among different anaesthetics.

We compared approximate equipotent vapour concen- trations of sevoflurane $4.5 \%$ in oxygen and halothane $2 \%$ in oxygen. Overall, subjects in the S Group had fewer complications than those in the $\mathrm{H}$ Group $(17.6 \%, 33.3 \%$, respectively, $P<0.05$ ). However, coughing and movement were mild in all subjects. Based on our results, sevoflurane exhibits less airway irritation and a more pleasant aroma than halothane. Sixty-five percent of subjects in the sevoflurane group classified the smell as pleasant compared with $13 \%$ of subjects in the halothane group $(P<0.05)$. Subjects in both groups found this type of rapid inhalation induction to be acceptable.

With both agents, cardiovascular instability was not noticeable despite the VCB at the high anaesthetic concentrations used which may have impeded venous return. Hypoxia did not occur with this technique although the subjects were not preoxygenated and held their breath at vital capacity.

In conclusion, we have shown that VCRII of anaesthesia with either halothane or sevoflurane is an effective technique. Our subjects found VCRII with both anaesthetics acceptable. However, the slower speed of induction with halothane frustrated the anaesthetist because of the longer induction time, and may increase the chance of pronounced excitatory phenomena. While sevoflurane had few complications and did not exhibit cardiovascular instability, we believe that sevoflurane offers a better alternative to halothane for the inhalational induced anaesthesia using VCRII technique.

\section{References}

1 Ruffle JM, Snider MT, Rosenberger JL, Latta WB. Rapid induction of halothane anaesthesia in man. $\mathrm{Br} J$ Anaesth 1985; 57: 607-11.

2 Ruffle JM. Snider MT. Comparison of rapid and conventional inhalation inductions of halothane oxygen anesthesia in healthy men and women. Anesthesiology 1987; 67: 584-7.

3 Wilton NCT, Thomas VL. Single breath induction of anaesthesia, using a vital capacity breath of halothane, nitrous oxide and oxygen. Anaesthesia 1986; 41: 472-6.

4 Inhalational induction of anaesthesia - new inspiration? (Editorial). Lancet 1986b; 2: 84.

5 Lamberty JM, Wilson IH. Single breath induction of anaesthesia with isoflurane. Br J Anaesth 1987; 59: 1214-8.

6 Bourne JG. General anaesthesia for out-patients with special reference to dental extraction. Proc R Soc Med 1954; 47: 416-20.

7 Eger El II. Anesthesia Uptake and Action. Baltimore: Williams \& Wilkins, 1974; 122-45. 